\title{
クロムはヒトの栄養にとって必須の微量元素だろうか？
}

\author{
吉田宗 弘 \\ 関西大学化学生命工学部
}

\section{Is Chromium an Essential Trace Element in Human Nutrition?}

\author{
Munehiro YOSHIDA \\ Faculty of Chemistry, Materials and Bioengineering, Kansai University
}

\begin{abstract}
It has been recognized that chromium is an essential trace element associated with carbohydrate metabolism, and chromium deficiency causes an impaired glucose tolerance. Recently, however, Vincent et al. have reported that chromium is not an essential trace element. In the present report, the author evaluated the nutritional essentiality of chromium by reviewing several previous reports. In almost all previous reports, the chromium concentration in the animal feed used was higher than $0.1 \mu \mathrm{g} / \mathrm{g}$, and it is difficult to consider that the experimental animals were in a low-chromium state. In addition, the amount of chromium administered to the animals for the improvement of glucose tolerance was at a pharmacological level, and corresponded to a level that far exceeded the human daily chromium intake ( 20 to $80 \mu \mathrm{g} / \mathrm{day}$ ). On the other hand, recent research has clearly shown that feeding with a severely low-chromium diet $(0.016 \mu \mathrm{g} / \mathrm{g})$ does not impair glucose tolerance. The amount of chromium absorbed in humans estimated from chromium intake (20 to $80 \mu \mathrm{g} / \mathrm{day})$, chromium absorption rate $(1 \%)$, and urinary chromium excretion $(<1 \mu \mathrm{g} / \mathrm{day})$ is less than $1 \mu \mathrm{g} / \mathrm{day}$, which is much lower than those of other essential trace elements. In addition, because there is an inconsistency between the chromium concentration in food and chromium intake, chromium intake seems to be dependent on chromium contamination during food processing and cooking. It is concluded that there is a high possibility that chromium is not an essential trace element.
\end{abstract}

Key words: chromium（クロム）, essentiality（必須性）, glucose tolerance (耐糖能),

Torula yeast（トルラ酵母), chromodulin（クロモデュリン), chromium intake（クロム摂取量）

はじめに

\begin{abstract}
栄養学の教科書には,「クロムはヒトを含む高等動物に とって必須の微量元素であり, 久乏した場合には耐糖能 が低下する」と記述されている。わが国の食事摂取基準 に抢いても, クロムは栄養上必要な微量ミネラルに位置 づけられて括り, 成人の摂取に対して推定平均必要量と 推奨量が設定されている(1)。糖代謝の維持や糖尿病予
\end{abstract}

受付 2012 年 6 月 16 日, 受理 2012 年 7 月 20 日

Reprint requests to: Munehiro YOSHIDA

Faculty of Chemistry, Materials and Bioengineering, Kansai University, 3-3-35 Yamate-cho, Suita, Osaka 564-8680, Japan

TEL: +81(6)6368-0970, FAX: +81(6)6388-8609

E-mail: hanmyou4@kansai-u.ac.jp
防を目的としたクロムサプリメントも販売されており， 米国ではカルシウムサプリメントに次ぐ売り上げがある という(2)。最近では, インスリンの作用を増強するク ロム含有オリゴペプチド（クロモデュリン）の存在も報 告され (3), 糖代謝に打けるク口ムの作用について分子 レベルでの理解も進んでいる。ところが，昨年，クロモ デュリンの命名者であるVincent は,「クロムは必須の栄 養素ではない」という論文を発表した（4）。本稿では，栄 養学領域におけるクロム研究の推移を概観し, 必須性に 対する疑義の根拠について述べる。

\section{1. 耐糖因子としてのクロム}

第二次世界大戦後，世界の人口が急激に増加し，マル 
サスの人口論，すなわち「人口の増加は土地の食糧生産 能力よりもはるかに大きく, 人口は幾何級数的に増加す るが食糧資源は算術級数的にしか増加しないため, やが て深刻な食糧不足が地球規模で発生する」という理論 （5）が現実味を帯び始めた。このため, 当時の栄養学に 課せられた命題は，新たな食糧資源，とくに新タンパク 質食糧資源を開拓することにあるとされた。これを受け て多くの栄養学者が single cell protein, すなわち酵母やク ロレラなどの単細胞生物をタンパク質源として活用する ための研究に取り組んだ。他方，工業社会の進展がもた らす環境污染に対処するため, 微生物よる環境浄化が実 用化された結果, 副産物としての微生物菌体が大量に得 られるよらになった。このよらな状況に打いて，主にパ ルプ廃液の処理に利用されていた卜ルラ酵母を七トや家 畜のタンパク質源に活用することが検討され，トルラ酵 母の乾燥菌体を唯一のタンパク質源とした飼料で実験動 物を飼育することが数多く実施された。

米国の Schwarz は，ラットにトルラ酵母をタンパク質 源とした飼料を与えると肝臓の壞死が生じることを認め た。彼は，この異常を未知の栄養素の久乏であると考兄， ビール酵母で飼育したラットに異常が出現しないことか ら, この未知の栄養素をビール酵母から発見しょうと試 久た。その結果, 肝臟壊死の予防には含硫了ミノ酸とビ タミン Eに加えて第 3 の因子 (factor 3) が必要であるこ とを見いだした（6)。そして，factor 3 にセレンが含まれ ることを示し, セレンが高等動物にとって必須の微量元 素である可能性が高いと発表した（7)。この発見は, こ れまで毒性元素とみなされていたセレンを栄養素として とらえたものであり，栄養学の歴史に执いてエポックを 形成したものといわれている。

Schwarz の共同研究者であった Mertzは, セレンの必須 性を示す研究の過程で，トルラ酵母で飼育したラットで は肝臓壊死を起こす前に耐糖能低下が生じることを観察 し, ビール酔母からの抽出物が耐糖能低下を改善するこ とを認めた (8)。彼らは, 肝蔵壊死と同様に, 微量元素 の久乏が耐糖能低下を起こすと推定して種々の微量元素 をラットに投与し, 最終的に三価クロム化合物が耐糖能 低下を改善することを見いだした（9)。そして，クロム 久乏が耐糖能低下を起こし，ビール酵母抽出物には耐糖 能を正常に維持するための耐糖因子（glucose tolerance factor: GTF）といらクロムを含㐊機能性物質が存在する と主張した。セレンの例があったためか，彼らの主張は 多くの栄養学者に受け容れられ, クロムもセレンと同様 の必須微量元素であるとの認識が広まった。その後，多 くの研究者によって GTF 単離の試みが様々な食品や動 物の臓器を用いて行われ，GTFの構造には数種のアミノ 酸とニコチン酸が含まれる可能性が示唆された (10)。乙 かし，現在にいたるまで，GTFの単離・構造決定はなさ れていない。

\section{2. クロムによる糖代謝異常の改善とクロモデュリン}

\section{2-1. 糖代謝異常の改善}

三価クロムに耐糖能改善効果があるという Schwarz と Mertzの主張を背景として, 糖代謝異常を起こした症例に クロムを投与する試みが開始された。その結果，200〜 $1,000 \mu \mathrm{g} / \mathrm{day}$ の三価クロム化合物の投与が 2 型糖尿病の諸 症状（血糖值，耐糖能など）を改善することが明らかと なった（11）。とくにクロム非添加高カロリ一輸液の長期 投与中に発生した糖代謝異常の症例では, クロム出納が負 であり，血中および毛髪クロム濃度（それぞれ $0.55 \mathrm{ng} / \mathrm{ml}$ と $154 \sim 175 \mathrm{ng} / \mathrm{g}$ ) が健常者（それぞれ，4.9〜9.5 ng/ml と>500 ng/g) に比較して明らかに低下していた（12）。さ らに, 糖㽷病患者では, クロムの尿中排泄量が増加して いることも示された (13)。これらのことから，クロムの 摂取不足，もしくはクロム代謝の異常による体内クロム の減少が糖代謝異常を引き起こすことは明らかであり, クロムが糖代謝に関わる必須微量元素であることは疑い ようもない事実であると思われるようになった。

\section{2-2. クロム含有オリゴペプチドの発見}

クロムの動物体内に打ける挙動を分子レベルで解明す る試みも数多く行われた。1980年代にYamamoto と Wada らは，クロムを投与した動物の臓器にクロムの結合した 低分子化合物が存在することを示した（14）。ウサギの肝 臓から単離されたものは, 分子量が約 1,500 のグリシン, システイン，アスパラギン酸，グルタミン酸によって構 成されるオリゴペプチドであり，全アミノ酸残基の半数 以上にカルボキシル基が存在し，1 分子当たり 4 分子の 3 価クロムが結合していた（15）。彼らは，クロムの結合し ていないアポ体が存在することに着目し，このオリゴペ プチドの役割を，クロムを速やかに尿へ排泄してクロム 中毒を防ぐことにあると考察した。

\section{2-3. クロモデュリン}

先述の高カロリ一輸液投与の症例においてインスリン 投与のみでは完全な回復が認められなかったことなどか ら，クロム投与による耐糖能の改善はクロムがインスリ ンの作用を増強することを意味すると思われた。 Yamamoto と Wada らは, 牛の乳腺から単離されたクロム 含有オリゴペプチドは，肝蔵などから単離されたものと クロムとのモル比が異なっているが，ラット脂肪細胞に おいてインスリンに依存したグルコース代謝を増強する ことを認めた（16）。その後, 1990 年代後半に, Vincent らは，クロム含有オリゴペプチドがインスリン受容体の チロシンキナーゼ活性と脂肪細胞の膜に結合したホスホ チロシンホスファターゼの活性を高めることを認めた $(17,18)$ ○らに，クロムの結合していないアポ体のオリ ゴペプチドには活性増強作用のないこと，増強作用はク ロム結合数の増加とともに高まって最大作用には 4 分子 の三価クロムの結合が必要であることも判明し，この才 
リゴペプチドの作用にはクロムが必須であることが明ら かになった（17）。

Vincentは，これらの結果にもとづき，クロム含有オリ ゴペプチドは，以下のような機構によってインスリンを 介した細胞内シグナル伝達に関わって扔り，クロモデュ リンと命名すべきものと提唱した $(3,19)$ 。すなわち，イ ンスリンが細胞膜のインスリン受容体に結合すると，イ ンスリン受容体の立体構造が変化してチロシンキナーゼ 活性が生じ，インスリンを介したシグナル伝達が開始さ れ，最終的にグルコース輸送担体が細胞膜表面に出現し て血中グルコースは速やかに細胞内に取り込まれる。こ のプロセスにおいて，血中クロムは，拈そらく血中イン スリン濃度の上昇を引き金として細胞内に取り込まれ， 貯えられていたアポクロモデュリンに結合する。生じた ホロクロモデュリンは，インスリン受容体に結合して立 体構造の変化を支え, チロシンキナーゼ活性を維持する。 血中グルコース濃度が低下し, 血中インスリンレベルが 低下寸ると，インスリン受容体の立体構造はゆるみ，ホ ロクロモデュリンも細胞内から血中へ移行して最終的に 尿に排泄される。な抏，血中クロム濃度の維持，打よび 血中から細胞へのクロムの輸送にはトランスフェリンが 関わることも示されている $(20)$ 。

\section{3. クロムは必須微量元素の条件を満たしているか}

クロモデュリン活性の発現にクロムが必須であること から, Vincent が提唱したクロモデュリンの作用機構は必 須微量元素としてのクロムの地位を盤石にするものと思 われた。ところがVincent 自身がクロムの必須性を否定 する主張を行っている。ここではクロムを必須微量元素 と認めない根拠を述べる。

\section{3-1. 必須微量元素の条件}

まず，必須微量元素というためにはどのような基準を 満たす必要があるのかを考劣てみる。クロムを栄養素の 列に加えた Mertzはこの基準についてしばしば言及して いる。彼の定義はしばしば変化しているが，吉野によれ ば，1980年頃には表 1 に記す 3 基準を満たすものが必須 微量元素であるとしていた（21）。しかし，分析技術が発

\section{表 1 必須微量元素であるための基準}

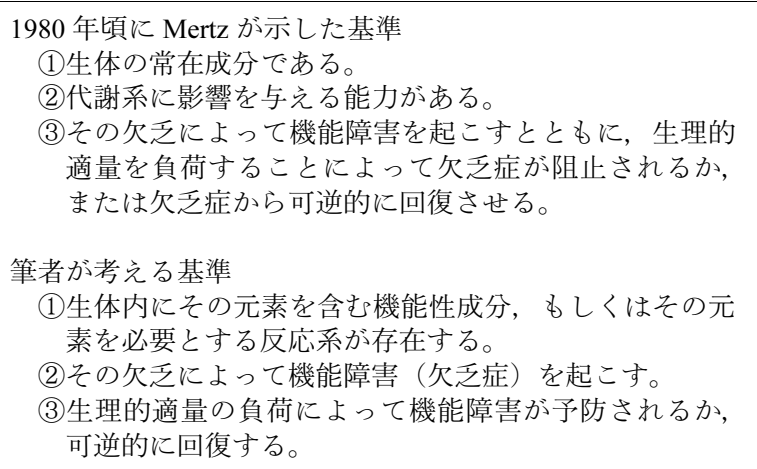

達した現在ではほとんどの元素が生体から検出できるの で，基準(1)はあまり意味がない。むしろ(2)とあわせて， 「生体内にその元素を含む機能性成分, もしくはその元素 を必要とする反応系が存在する」とするのが適切と判断 する。また，基準(3については，機能障害の発生と予防・

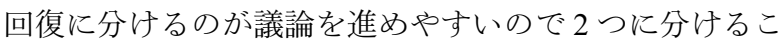
とにする。以上から，筆者が考える必須微量元素である ための基準も表 1 に記した。本稿ではこの筆者による基 準にもとづき微量元素の必須性を考える。

\section{3-2. クロム欠乏飼料とクロム投与量}

筆者が示した条件に照らして，クロムの必須性を検証 してみる。ラットに発生した耐糖能低下は機能障害に含 まれ，これがクロム投与によって改善している。クロム 投与量が生理的適量であるかの議論があるが，一応，基 準(3)満たしているとする。また，基準(1)もクロモデュ リンといらクロム含有機能性分子の存在によって満たさ れている。問題は基準(2)である。クロム欠乏飼料で飼育 した動物にクロムを投与して耐糖能が改善したとする報 告が数多く存在しているので，一見，満たされているよ らに見觉る。しかし，これらの報告で用いられた飼料は 本当に“クロム欠乏”飼料と呼べるものであっただろら か。Vincent の指摘もこの点にある。

表 2 は成人のクロム摂取量を推定した報告をまとめた ものである(22-29)。クロム摂取量の推定值は打拈むね $20 \sim 80 \mu \mathrm{g} / \mathrm{day}$ の範囲にある。また，わが国の食事摂取基

\section{表 2 クロム摂取量の推定値}

\begin{tabular}{llccc}
\hline \multicolumn{1}{r}{ 国 } & \multicolumn{1}{c}{ 推定法 } & $\begin{array}{c}\text { クロム摂取量 } \\
(\mu \mathrm{g} / \mathrm{day})\end{array}$ & 発表年 & 文献 \\
\hline フランス & 高齢者献立の分析 & $40 \pm 14$ & 2007 & $(22)$ \\
スペイン & 病院一般食の分析 & $77 \pm 17$ & 2008 & $(23)$ \\
ベルギー & 病院や軍隊の食事の分析 & $53 \pm 31$ & 1995 & $(24)$ \\
メキシュ & 食品分析値からの算定 & $30 \pm 2$ & 2001 & $(25)$ \\
日本 & 一般家庭献立の分析 & $47 \pm 33$ & 1988 & $(26)$ \\
& 菜食者献立の分析 & $27 \pm 8$ & 2011 & $(27)$ \\
アメリカ & 病院一般食の分析 & $43 \pm 20$ & 2011 & $(28)$ \\
& 一般成人献立の分析 & $33 \pm 3$ & 1985 & $(29)$ \\
\hline
\end{tabular}


準に拈ける成人のクロムの推定平均必要量は $20 \sim 35$ $\mu \mathrm{g} /$ day である（1）。したがって，ヒトでは摂取量が 20 $\mu \mathrm{g} / \mathrm{day}$ を回らなければクロム不足とはいえない。ヒト の 1 日の食事を凍結乾燥すると $400 \mathrm{~g}$ 程度になるので, ヒ 卜の摂取量 $20 \mu \mathrm{g} / \mathrm{day}$ は食事中濃度に換算すると約 $0.05 \mu \mathrm{g} / \mathrm{g}$ となる。この食事中濃度はラットの飼料中濃度 にほぼ相当するので，低クロム飼料と呼ぶには飼料中ク ロム濃度 $0.05 \mu \mathrm{g} / \mathrm{g}$ 未満が最低条件である。しかし, Mertz らの実験に打ける欠乏飼料のクロム濃度は記載されてい るもので $0.1 \mu \mathrm{g} / \mathrm{g}$ であり (30), ヒトの日常的なクロム摂 取量の範囲といえる。

クロム投与量についても，ヒトのクロム摂取量が $80 \mu \mathrm{g} / \mathrm{day}$ 未満であることを念頭に打く必要がある。しか し, Mertzらを含めて, 汇とんどの研究は, クロム濃度 2 または $5 \mu \mathrm{g} / \mathrm{mL}$ の飲料水をラットに与えている (30-32)。 この投与水準は，ヒトに換算すると $1,000 \sim 3,000 \mu \mathrm{g} / \mathrm{day}$ 程度のクロム投与となり, 薬理水準といえる。飼料にク ロムを添加する場合もヒトの摂取量 $80 \mu \mathrm{g} /$ day が飼料中 濃度 $0.2 \mu \mathrm{g} / \mathrm{g}$ に換算できるので，これを大幅に超える飼 料中ク口ム濃度 $1 \sim 2 \mu \mathrm{g} / \mathrm{g}$ は栄養水準とはいえない。

以上のことは，これまでの研究に拈いてクロム欠乏飼 料と称されてきたものの大半がヒトの日常のクロム摂取 量の範囲のクロム濃度であり, 耐糖能改善を目的として 投与されたクロムの量は日常の摂取量の数十倍に相当す る高水準だったことを意味している。つまり，過去の実 験結果は，薬理水準のクロム投与によって日常的なクロ ム摂取のラットの耐糖能が “向上”したことを観察した に過ぎないといえる。

なお，Schwarz と Mertzの実験では，トルラ酵母を与え たラットの耐糖能の低下を当時の一般的な精製飼料を与 えたラットと比較した上で示して拈り（9），トルラ酵母 投与によって耐糖能低下が生じたことは事実のよらであ る。彼らの用いたトルラ酵母はパルプ廃液を資化したも のであると思われるが，このよらなトルラ酵母にはリグ ニン分解物に由来する芳香族化合物が混入しているた め, 様々な side effect の生じる可能性がある。たとえば 筆者らはパルプ廃液資化トルラ酵母を与えたラットにお いて成長抑制と肝臓の薬物代謝系がえ進することを認め ている（33）。また，パルプ廃液由来のトルラ酵母は相当 な異臭がして扣り，これをタンパク質源とする飼料を ラットに食べさせるには, 糖質源として約 $50 \%$ のショ糖 が加えて甘味を強くしなければならない $(8,33)$ 。トルラ 酵母飼料を投与したラットに打ける肝蔵壊死や耐糖能低 下の発生には，混入していた芳香族化合物や大量に加え られたショ糖が関わっているかもしれない。すなわち, 彼らの実験で発生した耐糖能低下の原因をクロム以外に 求めることは可能だと思われる。

\section{3-3. Vincent の実験と主張（4）}

Vincent は, ラット標準精製飼料である AIN93Gのミネ ラル配合からクロムを除き，クロム濃度 $0.016 \mu \mathrm{g} / \mathrm{g}$ と
いらこれまでにない低クロム飼料を調製した。さらに, 飼育用具に金属素材を避けるなど，飼育環境からのクロ ム污染を極力除く努力も行った。そして，ラットを4群 に分け，1群にはこの低クロム飼料，他の 3 群には，そ れぞれ通常のAIN93G飼料（ク口ム濃度 $1.135 \mu \mathrm{g} / \mathrm{g}$ ), AIN93G $0.2 \mu \mathrm{g} / \mathrm{g}$ のクロムを添加した飼料 (クロム濃度 $1.331 \mu \mathrm{g} / \mathrm{g})$, AIN93G に $1.0 \mu \mathrm{g} / \mathrm{g}$ のクムを添加した飼料 (クロム濃度 $2.080 \mu \mathrm{g} / \mathrm{g}$ ) を与えて約 6 か月間飼育した後, 耐糖試験を行った。血糖值の变化量を積分したArea under curve (AUC) を比較すると, $1.0 \mu \mathrm{g} / \mathrm{g}$ クロム添加群 が AIN93G 群に比べて有意に低い值となった。また，試 験中の血中インスリン濃度の AUC はクロム摂取量に依 存して小さくなり, $1.0 \mu \mathrm{g} / \mathrm{g}$ クロム投与群が最低值を示し た。ただし，いずれの指標に打いても，低クロム群と AIN93G 群との間に有意差は認められなかった。Vincent は, 低クロム群とAIN93G 群との間に有意差のないこと から，耐糖試験に打いて血糖值やインスリン濃度に差が 生じるには薬理水準のクロム投与が必要であると述べ, これまでの研究で認められたクロムの効果は栄養素とし ての作用ではなく薬理作用であると結論している。そし て，クロムは必須微量元素ではないと主張している。

AIN93Gのクロム濃度がヒト食事換算では $400 \mu \mathrm{g} / \mathrm{day}$ 程 度のクロム摂取に相当して抢り，ヒトの摂取範囲に該当 する群が設定されていないことにやや不満は感じる。し かし, Vincent はAIN93G がラットの標準飼料であること を重視し，これを栄養的に適切なクロムを摂取する群と 位置づけて低クロム飼料投与群と比較したといえる。 Vincent と同様に, 飼料中濃度 $0.03 \mu \mathrm{g} / \mathrm{g}$ の低クロム飼料を 用いて，飼料中濃度 $1 \mu \mathrm{g} / \mathrm{g}$ のクム投与が耐糖能に影響 を与えないことを示す研究が存在することから (34), ラットの耐糖試験に拈いてクロムの効果が生じるには, 飼料中濃度 $1 \mu \mathrm{g} / \mathrm{g}$ では不十分であり，2 $2 \mathrm{~g} / \mathrm{g}$ といら高い 水準の摂取が必要であることは確かである。先の必須微 量元素に関する筆者の基準に照らした場合，低クロム飼 料群が AIN93G 飼料群に比較して耐糖能低下を起こして いないことから，基準(2)がクリアできていないことは明 白である。つまり, Vincent の主張はきわめて妥当なもの といえる。

なお，Mertzは 1980 年代より後になって，欠乏症発生 を必須微量元素の基準からはずし，代わりに「適量を摂 取することによって健康の増進に寄与する」を加えるこ とを提唱している(35)。この条件であれば，ら歯予防効 果を持つフッ素なども必須微量元素の仲間に加わること になり，薬理水準ではあっても耐糖能を“向上”させた クロムも必須微量元素となる。しかし，薬は予防や健康 増進に関するものであったとしても栄養素ではない。ゆ えにMertzの提唱に同意することはできない。

\section{4. クロムサプリメントの効果}

最初にも述べたが，米国では，糖尿病予防などを目的 
としたクロムサプリメントの人気が高い。しかし，集団 を対象としたクロムサプリメント投与に関するシステマ チックレビューは, $200 \sim 1,000 \mu \mathrm{g} / \mathrm{day}$ のクロム化合物投 与は, 2 型糖尿病患者の空腹時血糖值とへモグロビン A1 濃度を低下させるが，健常者の糖および脂質代謝に対し て有益な効果はいっさいないと述べている(36)。つま り, $200 \sim 1,000 \mu \mathrm{g} / \mathrm{day}$ のクム投与は, 起こってしまっ た糖代謝異常には効果があるが，健常者の糖代謝をさら に向上させる効果はないといえる。ただし, 健常者を対 象として，クロムサプリメント投与と糖尿病発症率との 関連を検討した前向きの疫学研究が見当たらないので, クロムサプリメントに糖尿病予防効果があるかは不明で ある。な拉，このシステマチックレビューでは，クロム 源がビール酵母の場合はクロム投与量が $10 \mu \mathrm{g} / \mathrm{day}$ 未満 でも糖尿病患者の血糖值が低下寸ることを示している。 これに関して，ビール酵母中のクロムの bioavailabilityが 高いとする主張もあるが，ビール酵母にはクロムと無関 係な GTF も存在するとも考兄られる。

\section{5. クロムパラドックス}

食品のクロム含有量，クロム摂取量，吸収率，尿中排 泄量, 体内量, クロム出納に関するこれまでの報告をつな いでいくと辻褄の合わないことがいくつか認められる。

\section{5-1. 食品中含有量と摂取量}

これまで日本の食品成分表にはクロム含有量の記載が ないため，献立作成時にクロム摂取量が食事摂取基準の 数值に見合っているかを確認できなかった。この事態に 対処するため, 一昨年の秋に刊行された日本食品標準成 分表 2010（以下，成分表と略記）では，これまで記載の なかったヨウ素，七レン，クロム，モリブデン，およびビ オチンの含有量が初めて記載された (37)。数值記載の対 象となったのは全体の 3 分の 1 に相当する約 500 食品で あるが，日常の食生活に拈いて高頻度に出現する食品は ほぼ網羅されて打り，一般的な献立であればクロム摂取 量を算定することは可能である。ところが，この成分表 を用いて日本人のクロム摂取量を算定すると $10 \mu \mathrm{g} / \mathrm{day}$ 未満といら数值が得られ (38), 表 2 に示したこれまでの 摂取量推定值との間に大きな乘離が認められる。同一献 立について成分表からの計算值と実測值を比較しても同 様の結果が得られる (28)。乘離の原因は, 成分表に記載 されている食品のクロム含有量がこれまで報告されてき たものに比較してあまりにも低いことにある。クロム分 析值が時代とともに低い值になっていることが有名であ るため, 数值が低いほど信頼性が高いという思い込みが クロム研究者にあるが，それにしても日本の成分表のク ロムの数值は低すぎるのではないかという印象が強い。

成分表からのクロム摂取量算定值は, 出納実験にもと づいて設定された食事摂取基準におけるクロム摂取の推 定平均必要量を大きく下回っている。このため, 単純に
表 3 クロム含有量の高い食品（ $\mu \mathrm{g} / 100 \mathrm{~g} ）$

$\begin{array}{ll}\text { バジル, 粉末 } & 47 \\ \text { あ揖り, 素干し } & 41 \\ \text { パセリ, 乾燥物 } & 38 \\ \text { パプリカ, 粉末 } & 33 \\ \text { 刻みこんぶ } & 33 \\ \text { こしょう (黒), 粉末 } & 30 \\ \text { ほしひじき } & 24 \\ \text { ミルクチョコレート } & 24 \\ \text { カレー粉 } & 21 \\ \text { さんしょう } & 21 \\ \text { 紅茶, 葉 } & 18 \\ \text { とうがらし, 粉末 } & 17 \\ \text { シナモン, 粉末 } & 14 \\ \text { さらしあん } & 14 \\ \text { 黒砂糖 } & 13 \\ \text { かぼちゃ種, 味付け } & 13 \\ \text { こしょう (混合), 粉末 } & 12 \\ \text { まこんぶ, 素干し } & 11 \\ \text { カットわかめ } & 10\end{array}$

日本食品標準成分表 2010 より抜粋

摂取量算定值と拱取基準の数値を比較すると，日本の食 品はクロム含有量が少なく，日本人はクロム摂取不足で あることになってしまう。とくにクロムサプリメントが 日本でも販売されていることから，宣伝材料に使われる 可能性は高い。必須でない可能性が高い化学物質に対し て必要量や摂取の推奨量を定めることの是非も含めて, 至急に対応する必要がある。

表 3 は成分表に記載されたクロム含有量を数值の高い 食品から順に抜き出したものである。クロム含有量の高 い食品の大半は粉末化した香辛料と加工食品であり，穀 物, 豆, および生鮮食品の中に $100 \mathrm{~g}$ あたり $10 \mu \mathrm{g}$ を超え るクロム含有量のものは皆無である。クロムの分析にお いては周囲からのクロム污染に細心の注意を払らことが 要求される。加工食品のクロム含有量が高いこと, 拈よ び献立中クロム濃度に関して実測值が成分表からの算定 值を大きく上回ることは，献立に含まれるクロムの多く が調理加工中に紛れ込んだ可能性をらかがわせる。つま り, クロム摂取量は污染に依存して変化しているか子し れないのである。調理加工におけるクロム污染の実態を 検証した研究はないが，このような物質が必須の栄養素 であることは考えにくい。

\section{5-2. 吸収量}

食事から摂取されたクロムの吸収率は種々の条件に よって変動するといわれているが，米国の食事摂取基準 ではこれを平均 $1 \%$ と見積もって授乳婦のクロム摂取の 目安量を算定している(39)。最近の同位体を用いた動物 実験の結果はこの見積もりを支持している (40)。クロム 摂取量 $20 \sim 80 \mu \mathrm{g} / \mathrm{day}$ に吸収率 $1 \%$ を適用すると，食事 から体内に吸収されるクロムは $1 \mu \mathrm{g} / \mathrm{day}$ 未満ということ になる。ヨウ素, セレン，モリブデンは，摂取量もしく 
は必要量がクロムと同水準であるが，これらは消化管で 大半が吸収される。マンガンは吸収率が数 \%未満といわ れるが, 1 日摂取量が mg のオーダーであるため, 吸収量 はヨウ素やセレンとほぼ同水準となる。つまり, クロム の吸収量は，これまで知られている必須微量元素に比較 して 100 分の 1 未満であり，あまりにも少ないといわざ るを得ない。この点に打いてもクロムの必須性には疑問 がある。

クロムの主排泄経路は尿であると考兄らる(40)。尿 クロムの分析值は研究者ごとに差異が大きいが，最近は 吸収率 $1 \%$ に見合ら尿排泄量 $(1 \mu \mathrm{g} /$ day 未満) とする報告 が多い（41-43）。一方，クロムの体内量が加齢とともに 低下寸るといら報告 (44) があり, 連日ではないにしても クロム出納が負になっている可能性がある。たとえば母 乳へのクロム損失は $1 \mu \mathrm{g} / \mathrm{day} に$ 近いが (45), 吸収率が $1 \%$ であるとすると授乳婦では連日 $100 \mu \mathrm{g} / \mathrm{day}$ 程度の摂取が ないと出納は負になる。ただし, 高齢者を対象として行 われた実験では，クロム摂取量が $20 \sim 30 \mu \mathrm{g} / \mathrm{day}$ であっ ても正の出納值が得られている $(46,47)$ 。

\section{おわりに}

クロムの必須性に疑問を投げかける論文は以前から繰 り返し発表されていた $(48,49)$ 。Vincentの発表にインパ クトがあったのは，彼がクロム含有機能性分子であるク ロモデュリン研究の第一人者であったためである。本稿 で述べたように, 現状ではクロムの必須性を否定する論 理が優勢である。しかし，クロムが必須微量元素である 可能性はまだ残っている。ただし, Vincent 以上のクロム 欠乏動物を作成するのは技術的に困難なので，別の方法 を考える必要がある。クロモデュリンがクロムを含む機 能性分子であることは事実であるから，クロモデュリン が健康維持に必須の生体成分であることを示すことがで きれば，クロム欠乏による健康障害を実験的に起こさな くても, クロムを必須微量元素の列に加えることができ る。クロモデュリンの単離は, クロム投与動物の蔵器, あるいは採取後にクロム溶液に浸漬した臓器を材料とし て行われており，クロモデュリンの大半はアポ体で存在 していると考えられる。このアポクロモデュリンの合成 に関わる遺伝子をノックアウトし，何が起こるかを調べ るのは有効かもしれない。ただし，アポクロモデュリン の役割が別にあって，クロムが結合したクロモデュリン の作用は偶然の産物であるといらことが判明する可能性 もある。

一方，クロムの摂取，吸収，排泄に関するいくつかの パラドックスを解消するには, クロムの正確な定量分析 が必須である。食事，血液，尿などを対象としたク口ム の分析に拈いては, 標準参照試料を用いて測定値の正確 性を担保することが必要である。

\section{文献}

（1）厚生労働省. 日本人の食事摂取基準 [2010 年版 ]。東 京: 第一出版, 2009:218-275.

(2) Nielsen F. Controversial chromium: does the superstar mineral of the Mountebanks receive appropriate attention from clinicians and nutritionists? Nutrition Today 1997;31: 226-233.

( 3 ) Vincent JB. Recent advances in the nutritional biochemistry of trivalent chromium. Proc Nutr Soc 2004;63:41-47.

(4) Di Bona KR, Love S, Rhodes NR, McAdory D, Sinha SH, Kern N, Kent J, Strickland J, Wilson A, Beaird J, Ramage J, Rasco JF, Vincent JB. Chromium is not an essential trace element for mammals: effects of a "low-chromium" diet. J Biol Inorg Chem 2011;16:381-390.

（5）斉藤悦則訳. マルサス人口論. 東京 : 光文社， 2011.

(6) Schwarz K. A hitherto unrecognized factor against dietary necrotic liver degeneration in American yeast (factor 3). Proc Soc Exp Biol Med 1951;78:852-854.

(7) Schwarz K, Foltz CM. Selenium as an integral part of Factor 3 against dietary necrotic liver degeneration. J Am Chem Soc 1957;79:3292-3293.

(8) Mertz W, Schwarz K. Impaired intravenous glucose tolerance as an early sign of dietary necrotic liver degeneration. Arch Biochem Biophys 1955;58:504-506.

( 9 ) Schwarz K, Mertz W. Chromium (III) and the glucose tolerance factor. Arch Biochem Biophys 1959;85:292-295.

(10) Steele NC, Althen TG, Frobish LT. Biological activity of glucose tolerance factor in swine. J Anim Sci. 1977;45: 1341-1345.

(11) Mertz W. Chromium in human nutrition: a review. J Nutr 1993;123:626-633.

(12) Jeejeebhoy KN, Chu RC, Marliss EB, Greenberg GR, Bruce-Robertson A. Chromium deficiency, glucose intolerance, and neuropathy reversed by chromium supplementation, in a patient receiving long-term total parenteral nutrition. Am J Clin Nutr 1977;30:531-538.

(13) Morris BW, MacNeil S, Hardisty CA, Heller S, Burgin C, Gray TA. Chromium homeostasis in patients with type II (NIDDM) diabetes. J Trace Elem Med Biol 1999;13:57-61.

(14) Yamamoto A, Wada O, Ono T. A low-molecular-weight, chromium binding substance in mammals. Toxicol Appl Pharmacol 1981;59:515-523.

(15) Yamamoto A, Wada O, Ono T. Isolation of a biologically active low-molecular-mass chromium compound from rabbit liver. Eur J Biochem 1987;165:627-631.

(16) Yamamoto A, Wada O, Suzuki H. Purification and properties of biologically active chromium complex from bovine colostrum. J Nutr 1988;118:39-45.

(17) Davis CM, Vincent JB. Chromium oligopeptide activates insulin receptor tyrosine kinase activity. Biochemistry 1997;36:4382-4385.

(18) Davis CM, Sumrall KH, Vincent JB. A biologically active form of chromium may activate a membrane phosphotyrosine phosphatase (PTP). Biochemistry 1996;35:1296312969.

(19) Vincent JB. Quest for the molecular mechanism of chromi- 
um action and its relationship to diabetes. Nutr Rev 2000; 58:67-72.

(20) Clodfelder BJ, Emamaullee J, Hepburn DD, Chakov NE, Nettles HS, Vincent JB. The trail of chromium(III) in vivo from the blood to the urine: the roles of transferrin and chromodulin. J Biol Inorg Chem 2001;6:608-617.

（21）吉野芳夫. 無機質の代謝. 細谷憲政編, 栄養学 (2) 代 謝と生理. 東京: 有斐閣, 1980:141-167.

(22) Roussel AM, Andriollo-Sanchez M, Ferry M, Bryden NA, Anderson RA. Food chromium content, dietary chromium intake and related biological variables in French free-living elderly. Br J Nutr 2007;98:326-331.

(23) Velasco-Reynold C, Navarro-Alarcon M, De La Serrana HL, Perez-Valero V, Lopez-Martinez MC. Determination of daily dietary intake of chromium by duplicate diet sampling: in vitro availability study. Food Addit Contam 2008; 25:604-610.

(24) Van Cauwenbergh R, Hendrix P, Robberecht H, Deelstra HA. Daily dietary chromium intake in Belgium, using duplicate portion sampling. Z Lebensm Unters Forsch 1996; 203:203-206.

(25) Grijalva Haro MI, Ballesteros Vázquez MN, Cabrera Pacheco RM. Chromium content in foods and dietary intake estimation in the Northwest of Mexico. Arch Latinoam Nutr 2001;51:105-110.

（26）池辺克彦，田中之雄，田中凉一. 陰膳方式による 15 金 属元素の一日摂取量について. 食衛誌 1988;29:52-57.

(27) Yoshida M, Ôgi N, Iwashita Y. Estimation of mineral and trace element intake in vegans living in Japan by chemical analysis of duplicate diets. Health 2011;3:672-676.

（28）吉田宗弘, 児島未希奈, 三由亜耶, 森田明美. 病院打 よび介護施設の食事からの微量ミネラル摂取量の計 算值と実測值との比較. 微量栄養素研究 2011;28:27-31.

(29) Anderson RA, Kozlovsky AS. Chromium intake, absorption and excretion of subjects consuming self-selected diets. Am J Clin Nutr 1985;41:1177-1183.

(30) Mertz W, Roginski EE, Schroeder HA. Some aspects of glucose metabolism of chromium-deficient rats raised in a strictly controlled environment. J Nutr 1965;86:107-112.

(31) Striffler JS, Law JS, Polansky MM, Bhathena SJ, Anderson RA. Chromium improves insulin response to glucose in rats. Metabolism 1995;44:1314-1320.

(32) Scroeder HA. Chromium deficiency in rats: A syndrome simulating diabetes mellitus with retarded growth. J Nutr 1966;88:439-445.

（33）吉田宗弘, 小野聡子, 舘 博, 安藤達彦. セレン欠 乏飼料としてのトルラ酵母の再評価. 微量栄養素研究 1995;12:131-135.

(34) Flatt PR, Juntti-Berggren L, Berggren PO, Gould BJ, Swanston-Flatt SK. Effects of dietary inorganic trivalent chromium $(\mathrm{Cr} 3+)$ on the development of glucose homeostasis in rats. Diabete Metab 1989;15:93-97.
(35) Mertz W. Essential trace metals: new definitions based on new paradigms. Nutr Rev 1993;51:287-295.

(36) Balk EM, Tatsioni A, Lichtenstein AH, Lau J, Pittas AG. Effect of chromium supplementation on glucose metabolism and lipids: a systematic review of randomized controlled trials. Diabetes Care 2007;30:2154-2163.

（37）文部科学省学術審議会資源調査分科会. 日本食品標準 成分表 2010．東京：全国官報販売協同組合，2010．

（38）加藤友紀，大塚 礼，今井具子，安藤富士子，下方浩 史. 地域在住中高年者の微量ミネラルおよびビオチン の摂取量. 栄食誌 2012;65:21-28.

(39) Food and Nutrition Board, Institute of Medicine. Chromium. In: Dietary Reference Intakes for Vitamin A, Vitamin K, Arsenic, Boron, Chromium, Copper, Iodine, Iron, Manganese, Molybdenum, Nickel, Silicon, Vanadium, and Zinc. Washington DC: National Academic Press, 2001:197-223.

(40) Kottwitz K, Laschinsky N, Fischer R, Nielsen P. Absorption, excretion and retention of $51 \mathrm{Cr}$ from labeled $\mathrm{Cr}$-(III)picolinate in rats. Biometals 2009;22:289-295.

(41) Nomiyama H, Yotoriyama M, Nomiyama K. Normal chromium levels in urine and blood of Japanese subjects determined by direct flameless atomic absorption spectrophotometry, and valency of chromium in urine after exposure to hexavalent chromium. Am Ind Hyg Assoc J 1980;41:98102 .

(42) Hajifaraji M, Leeds AR. The effect of high and low glycemic index diets on urinary chromium in healthy individuals: a cross-over study. Arch Iran Med 2008;11:57-64.

(43) Bahijri SM, Alissa EM. Increased insulin resistance is associated with increased urinary excretion of chromium in nondiabetic, normotensive Saudi adults. J Clin Biochem Nutr 2011;49:164-168.

(44) Davies S, Howard JM, Hunnisett A, Howard M. Agerelated decreases in chromium levels in 51,665 hair, sweat, and serum sample from 40,872 patients. Implications for the prevention of cardiovascular disease and type II diabetes mellitus. Metabolism 1997;46:469-473.

(45) Yoshida M, Takada A, Hirose J, Endô M, Fukuwatari T, Shibata K. Molybdenum and chromium concentrations in breast milk from Japanese women. Biosci Biotechnol Biochem 2008;72:2247-2250.

(46) Bunker VW, Lawson MS, Delves HT, Clayton BE. The uptake and excretion of chromium by the elderly. Am J Clin Nutr 1984;39:797-802.

(47) Offenbacher EG, Spencer H, Dowling HJ, Pi-Sunyer FX. Metabolic chromium balances in men. Am J Clin Nutr 1986;44:77-82.

(48) Stearns DM. Is chromium a trace essential metal? Biofactors 2000;11:149-162.

(49) Editorial Board of Nutrition Reviews. Is chromium essential for humans? Nutr Rev 1988;46:17-20. 